\title{
ОТ ГЛАВНОГО РЕДАКТОРА
}

Этот номер, последний в 2013 г., открывается статьей Т.И. Горкиной (Институт географии РАН), посвященной геополитическим проблемам Арктики. Автором подробно рассматриваются задачи и важнейшие направления международного сотрудничества арктических государств, а также существенные различия в позициях их правительств по вопросу делимитации границ и будущего использования арктического пространства. Большое внимание в статье уделяется также оценке возможных последствий глобального потепления климата для всей циркумполярной зоны и его влияния на геоэкономические и геополитические процессы в Арктике.

В разделе “Территориальная организация общества" на этот раз помещены четыре статьи. Н.В. Мкртчян (Институт демографии НИУ ВШЭ) анализирует миграцию молодежи на уровне городов и районов в 19 регионах России на основе данных за 1989-2002 и 2003-2010 гг. Притягивали молодежь все региональные столицы, что позитивно сказывалось на возрастной структуре их населения, “удерживать” молодежь могли только крупные города. Выявлено, что потери молодежи периферией нарастают по мере удаления от региональных центров, причем в малых и средних городах на периферии регионов отток молодежи почти всегда достигает той же интенсивности, что и в сельской местности.

О роли миграции в освоении территории и формировании населения идет речь еще в двух статьях этого раздела, причем обе они посвящены Дальневосточным регионам и обе написаны сотрудниками Института комплексного анализа региональных проблем ДВО РАН в г. Биробиджане. С.Н. Мищук представляет результаты ретроспективного анализа заселения Дальнего Востока России с середины XIX в. по настоящее время, который позволил выявить факторы формирования и динамику миграционных потоков; один из аспектов исследования - внешние миграции и привлечение иностранной рабочей силы. Очень важны выводы автора о неудовлетворительных итогах освоения рассматриваемой территории переселенцами из европейской части России в первый период (до 1926 г.), особенностях решения проблемы дефицита рабочей силы в 19271987 гг., роли противоположно направленных миграционных потоков (внутрироссийского и международного) в последние 20 лет.
Статья И.В. Калининой и Т.M. Комаровой посвящена чрезвычайно актуальной теме социально-демографической безопасности приграничного региона России. Проанализированы формирование расселения в Еврейской автономной области с 1930-х годов по настоящее время и геодемографическая ситуация в муниципальных районах в последнее двадцатилетие. Сделан вывод, что начиная с конца XX в. территории, концентрирующие более $70 \%$ населения области, относятся к зоне социально-демографической напряженности. В связи с этим авторы подчеркивают принципиальную сложность осуществления функции социального контроля над территорией в сельской местности рассматриваемого региона. Градиент в освоенности и заселенности приграничных районов Еврейской автономной области и Китая прекрасно иллюстрирует составленная авторами карта, на которую следует специально обратить внимание читателей.

В четвертой статье раздела Н.С. Булинина (Нижегородский государственный педагогический университет им. К. Минина) анализирует процесс трансформации городского пространства Нижнего Новгорода в постсоветский период на примере размещения объектов третичного сектора экономики (сферы торговли и услуг).

В разделе "Природные процессы и динамика геосистем” мы публикуем две статьи, посвященные атмосферным засухам. В статье, написанной А.Б. Шмакиным, жизнь которого трагически оборвалась 28 июня 2013 г. на 52-м году жизни, с сотрудниками лаборатории климатологии Института географии РАН М.М. Чернавской и В.В. Поповой, представлен всесторонний анализ пространственно-временной структуры рекордной жары лета 2010 г. на Европейской территории России. Для сравнения привлечены исторические источники о повторяемости подобных аномальных явлений в эпоху до начала сетевых метеорологических наблюдений. Показано, что в XIV-XVI вв. отмечалось по 2-3 сильные засухи за столетие. В генезисе засухи 2010 г. большую роль играли блокирующие антициклоны, в формировании которых заметно значение механизма WP (Западно-Тихоокеанского), проявляющегося наиболее заметно после 1980-х годов (то есть при современном потеплении). 
В статье Е.А. Черенковой, также сотрудника лаборатории климатологии Института географии РАН, рассмотрены вопросы повторяемости и масштабов охвата засухами регионов Европейской территории России в период 1936-2010 гг. Наиболее обширные и продолжительные засухи наблюдались с 1936 по 1939 г., а также в 1972 и 2010 гг. Особенность засухи 2010 г. заключалась в охвате одновременно Северо-Западного, Поволжского и Центрального федеральных округов и умеренном ее проявлении в Южном округе. Для оценки интенсивности и масштабов рассматриваемых явлений привлечены соответствующие коэффициенты и индексы (например, индекс суровости засух Пальмера, индекс Педя и др.).

Две статьи в этом разделе посвящены гидрологическим вопросам. С.В. Ясинский (Институт географии РАН) рассчитал элементы водного баланса для разных природных зон Волжского бассейна в мало- и многоводные фазы многолетнего периода. Установлено, в частности, что во всех природных зонах осадки и испарение в многоводную фазу превышают их величину в маловодную примерно в 1.2 раза. В степной зоне многолетние колебания суммарного речного стока асинхронны его изменениям в лесной зоне.

В статье Ю.А. Харанжевской (Сибирский НИИ сельского хозяйства и торфа Россельхозакадемии) рассмотрены многолетние изменения элементов водного баланса на водосборах ряда средних рек юга Западной Сибири. Проведен статистический анализ месячных гидрологических рядов за период 1969-2008 гг., включая их проверку на однородность. Сделан вывод об увеличении слоя стока в январе-марте и его снижении в теплый период года. Это, по мнению автора, будет способствовать усилению заболоченности региона.

Статья А.К. Марковой и А.Ю. Пузаченко (Институт географии РАН) с коллегами из Института экологии растений и животных УрО РАН (Екатеринбург), Института геологии Коми НЦ РАН (Сыктывкар), Московского государственного университета и Лейденского университета (Нидер- ланды), Зоологического института РАН (СанктПетербург), помещенная в разделе “Эволюция природных систем", посвящена динамике ареалов овцебыка и первобытного бизона на территории Северной Евразии в позднем плейстоцене и голоцене. На основе анализа новых поступлений базы данных (ПАЛЕОФАУНА) и радиоуглеродных датировок прослежены тенденции в реакции этих крупных травоядных млекопитающих "мамонтового комплекса" на изменения климата. Представлены карты местонахождений рассматриваемых видов в разные периоды позднего плейстоцена и высказаны мнения о причинах их вымирания.

В разделе "Природопользование и геоэкология" А.А Таратунин (Центральный научно-исследовательский институт комплексного использования водных ресурсов, Минск) в своей статье анализирует причины увеличения ущерба от наводнений в мире. Особое внимание уделяется слабому гидрологическому обоснованию проектов гидротехнических сооружений.

В статье Э.Г. Коломыца и Л.С. Шарой (Институт экологии Волжского бассейна РАН), помещенной в разделе "Геоинформационные системы и картографирование", изложена методика количественной оценки потенциальной устойчивости лесов как интегрального показателя их функционирования и динамики. В основу положены параметры биологического круговорота и значения факторов среды (климата). Для модельного района Среднего Поволжья составлены карты устойчивости лесов к изменениям климата.

Наш журнал регулярно освещает авторитетные научные форумы, крупные международные конференции, имеющие большое значение для развития географической науки и практики. В конце этого номера читатель найдет подготовленный директором Байкальского института природопользования Сибирского отделения РАН членом-корр. РАН А.К. Тулохоновым и его соавтором М.В. Слипенчуком обзор международной научной конференции "Байкал - всемирное наследие”, состоявшейся в апреле 2012 г. в штабквартире ЮНЕСКО. 